\title{
Editorial
}

\section{Human papillomavirus testing in cervical cancer screening}

\author{
S Franceschi' and C Mahé' \\ IInternational Agency for Research on Cancer, 150 cours Albert Thomas, 69372 Lyon cedex 08, France
}

British Journal of Cancer (2005) 92, I59 | - 1592. doi: I0.1038/sj.bjc.6602580 www.bjcancer.com

(c) 2005 Cancer Research UK

Research on the use of human papillomavirus (HPV) DNA testing in the screening and management (triage) of cervical lesions began in the late 1980s with the growing evidence that certain (high-risk (HR)) HPV types were the cause of cervical cancer (Walboomers et al, 1999; IARC, 2005). Since women not infected with HR HPV types, even with abnormal cytology, are at negligible risk for cervical cancer, HPV testing could be superior to cytology in cervical cancer screening (Cuzick et al, 1999; Nobbenhuis et al, 1999). Human papillomavirus testing may also be cost-effective if it allows for a longer screening interval, or for screening to be discontinued at an earlier age than currently recommended (i.e., 65 years). Follow-up studies of women with negative cytology, according to HPV status, are therefore important. In this issue, Bulkmans et al (2005) and Grainge et al (2005), using two different study designs, provide further evidence of the value of adding HPV testing to cervical cytology in screening programmes.

In their 5-year cohort study in The Netherlands of 2810 women aged 30-60 years with normal cytology, Bulkmans et al (2005) show that, in agreement with previous findings from the US (Sherman et al, 2003), France (Clavel et al, 2004) and the UK (Cuzick et al, 2003; Peto et al, 2004), HR HPV testing combined with cytology has higher sensitivity and higher negative predictive value for cervical intraepithelial neoplasia (CIN) 3 and cancer than cytology alone. Specificity was, however, slightly lower for HPV testing and cytology (93\%) than cytology alone (95\%).

The improvement in sensitivity and negative predictive value made possible by the addition of HR HPV testing to cytology supports the use of viral testing in order to increase the screening interval, although the findings of Bulkmans et al (2005) should be interpreted with some caution as their study was relatively small, and, as the authors emphasise, an increased sensitivity is implicit in performing any additional test (Franco and Ferenczy, 1999).

Also in this issue, Grainge et al (2005) report the findings of a nested case-control study based on women with a normal cytological smear between 1988 and 1992 (termed the baseline smear) who later, after an average of 6.8 years, received a histologically confirmed diagnosis of CIN 2 or worse. Excluding CIN2, which is biologically and clinically difficult to distinguish from CIN1, there were $346 \mathrm{CIN} 3$ cases and 51 cervical cancer cases together with 591 control women who never had cytological abnormalities. Although Grainge et al (2005) found a significantly higher HPV positivity among cases compared to controls, a substantial proportion of women tested negative for HPVs in baseline smears less than 4 years (67\%), and $4-13$ years (74\%), before the diagnosis of CIN3/cervical cancer. Unfortunately, such use of long-stored archived cervical smears is prone to the danger of false-negative HPV findings (De Roda, 1995) and crosscontamination (Chua and Hjerpe, 1995).

It is important to bear in mind, however, that the detection of $\mathrm{HPV}$ at a single point in time (as in case-control studies) or over a few years of follow-up (seldom more than 5 years in available cohort studies, Schiffman et al, 2005) does not allow an accurate estimate of a woman's lifelong risk of HPV infection nor of cervical cancer. Transiently detectable HPV infection is generally regarded as harmless, but the long-term prognosis of an HPV-positive finding is not fully understood. A follow-up study of 232 women with HR HPV infection in Manchester, UK, showed a cumulative rate of CIN3 or worse of $16 \%$ after 10 years (Peto et al, 2004). A lower CIN3 rate $(6 \%)$ was seen in the Portland study in the US (Sherman et al, 2003), in which women were examined, biopsied and treated more frequently than in the Manchester study.

At least two important issues are, therefore, still open: (a) whether HPV infection disappears or, in some instances, persists undetectably in the basal cells of the cervix, and (b) whether HR HPV infection without cervical abnormality should be observed or treated, and if so, when and how. These uncertainties must be resolved before HPV testing can replace cytology and new recommendations made about screening interval or early screening cessation (Peto et al, 2004).

Several large-scale randomised controlled trials are ongoing on these issues and their final results should become available within the next 2 or 3 years (Dillner, 2000; Bulkmans et al, 2004; Kitchener et al, 2004; Ronco et al, 2004). For the moment it is important to avoid the so-called 'implement now and trust' approach (Whynes, 2004). Apparent coincidence of interests between manufacturers, who see an enormous market for HPV tests, and women and physicians, who would favour any extra test for added reassurance, should not distract from the evaluation of the real benefit of using HPV testing in cervical cancer screening and its associated financial and emotional cost. Most importantly, enthusiasm for new technology should not eclipse the well-known requirements for good screening programmes, namely high coverage, quality control and follow-up (IARC, 2005). 


\section{REFERENCES}

Bulkmans NWJ, Rozendaal L, Snijders PJF, Voorhorst FJ, Boeke AJ, Zandwijken GR, van Kemenade FJ, Verheijen RH, Groningen K, Boon ME, Keuning HJ, van Ballegooijen M, van den Brule AJ, Meijer CJLM (2004) POBASCAM, a population-based randomized controlled trial for implementation of high-risk HPV testing in cervical screening: design, methods and baseline data of 44,102 women. Int J Cancer 110: $94-101$

Bulkmans NWJ, Rozendaal L, Voorhorst FJ, Snijders PJF, Meijer CJLM (2005) Long-term protective effect of high-risk human papillomavirus testing in population-based cervical screening. Br J Cancer 92: 1800-1802

Chua KL, Hjerpe A (1995) Polymerase chain reaction analysis of human papillomavirus in archival cervical cytologic smears. Anal Quant Cytol Histol 17: $221-229$

Clavel C, Cucherousset J, Lorenzato M, Caudroy S, Nou JM, Nazeyrollas P, Polette M, Bory JP, Gabriel R, Quereux C, Birembaut P (2004) Negative human papillomavirus testing in normal smears selects a population at low risk for developing high-grade cervical lesions. Br J Cancer 90: 1803 1808

Cuzick J, Sasieni P, Davies P, Adams J, Normand C, Frater A, van Ballegooijen M, van den Akker E (1999) A systematic review of the role of human papillomavirus testing within a cervical screening programme. Health Technol Assess 3: 1-196

Cuzick J, Szarewski A, Cubie H, Hulman G, Kitchener H, Luesley D, McGoogan E, Menon U, Terry G, Edwards R, Brooks C, Desai M, Gie C, Ho L, Jacobs I, Pickles C, Sasieni P (2003) Management of women who test positive for high-risk types of human papillomavirus: the HART study. Lancet 362: $1871-1876$

De Roda Husman A-M, Snijders PJF, Stel HV, van den Brule AJ, Meijer CJLM, Walboomers JM (1995) Processing of long-stored archival cervical smears for human papillomavirus detection by the polymerase chain reaction. Br J Cancer 72(2): $412-417$

Dillner J (2000) Cervical cancer screening in Sweden. Eur J Cancer 36: $2255-2259$

Franco EL, Ferenczy A (1999) Assessing gains in diagnostic utility when human papillomavirus is used as an adjunct to papanicolaou smear in the triage for women with cervical cytologic abnormalities. Am J Obstet Gynecol 181: $382-386$

Grainge MJ, Seth R, Coupland C, Guo L, Rittmen T, Vryenhoel P, Johnson J, Jenkins D, Neal KR (2005) Human papillomavirus infection in women who develop high grade cervical intraepithelial neoplasia or cervical cancer: a case-control study in the UK. Br J Cancer 92: 1794-1799

IARC (2005) IARC Handbooks of Cancer Prevention, Volume 10: Cervix Cancer Screening. Lyon: IARC Press

Kitchener H, Wheeler P, Desai M, Corbitt G, Roberts C, Maguire P, Fletcher I, Dowie R, Moss S, Gilham C, Peto J (2004) The ARTISTIC trial - a randomised trial in screening to improve cytology (abstract 268). 21st International Papillomavirus Conference, Mexico City, February 20-26, 2004

Nobbenhuis MA, Walboomers JM, Helmerhorst TJ, Rozendaal L, Remmink AJ, Risse EK, van der Linden HC, Voorhorst FJ, Kenemans P, Meijer CJLM (1999) Relation of human papillomavirus status to cervical lesions and consequences for cervical-cancer screening: a prospective study. Lancet 354: $20-25$

Peto J, Gilham C, Deacon J, Taylor C, Evans C, Binns W, Haywood M, Elanko N, Coleman D, Yule R, Desai M (2004) Cervical HPV infection and neoplasia in a large population-based prospective study: the Manchester cohort. Br J Cancer 91: 942-953

Ronco G, Segnan N, De Marco L, Rizzolo R, Ghiringhello B, Confortini M, Carozzi F, Zappa M, Iossa A, Vettorazzi M, Del Mistro A, Naldoni P, Sintoni C, Schincaglia P, Bondi A, Casadei GP, Dalla Palma P, Brezzi S, Giorgi-Rossi P, Pellegrini A, Cuzick J (2004) A randomized trial on HPV testing for primary screening of cervical cancer: preliminary results (abstract 338). 21st International Papillomavirus Conference, Mexico City, February 20-26, 2004

Schiffman M, Khan MJ, Solomon D, Herrero R, Wacholder S, Hildesheim A, Rodriguez AC, Bratti MC, Wheeler CM, Burk RD (2005) A study of the impact of adding HPV types to cervical cancer screening and triage tests. J Natl Cancer Inst 97: 147-150

Sherman ME, Lorincz AT, Scott DR, Wacholder S, Castle PE, Glass AG, Mielzynska-Lohnas I, Rush BB, Schiffman M (2003) Baseline cytology, human papillomavirus testing, and risk for cervical neoplasia: a 10-year cohort analysis. J Natl Cancer Inst 95: 46-52

Walboomers JM, Jacobs MV, Manos MM, Bosch FX, Kummer JA, Shah KV, Snijders PJF, Peto J, Meijer CJLM, Muñoz N (1999) Human papillomavirus is a necessary cause of invasive cervical cancer worldwide. J Pathol 189: $12-19$

Whynes DK (2004) Economics of cancer screening programs. Exp Rev Pharmacoeconomics Outcomes Res 4: 61-69 